\title{
Suppression of Verticillium Wilt of Eggplant by Earthworms
}

\author{
Wade H. Elmer, Plant Pathologist, and Francis J. Ferrandino, Associate Agricultural Scientist, The Connecticut \\ Agricultural Experiment Station, P.O. Box 1106, New Haven, CT 06504
}

\begin{abstract}
Elmer, W. H., and Ferrandino, F. J. 2009. Suppression of Verticillium wilt of eggplant by earthworms. Plant Dis. 93:485-489.

The role of earthworms in plant disease has received little attention. To address whether earthworms would affect the severity of Verticillium wilt of eggplant (Solanum melongena) in the field, we grew eggplants in experimental field plots that were naturally infested with Verticillium dahliae in 2005, 2006, and 2007. Three earthworm treatments were compared: (i) no treatment (untreated control), (ii) earthworm populations reduced via chemical eradicants (carbaryl or hot mustard) (reduced treatment), and (iii) earthworm populations increased by addition of adult Canadian nightcrawlers (Lumbricus terrestris, 11 earthworms per $\mathrm{m}^{2}$ ) (augmented treatment). Compared to the untreated control, the estimates of the area under the disease progress curve (AUDPC) were reduced while estimates of the canopy growth curve (CGC) and the final plant weights were increased in plots augmented with earthworms in all 3 years. In 2 out of 3 years, eggplant yield (weight and number of fruit) was increased in plots augmented with earthworms. When a carbaryl drench was used to reduce earthworm numbers, the treatment resulted in plants with more disease than in the untreated controls in 2005. However, in 2005 and 2006, carbaryltreated plants had larger CGC values and higher yield than in the untreated controls and were not significantly different from the augmented plots. When a hot mustard extraction procedure was used to reduce earthworm densities in 2007, plant growth, yield, and disease variables did not differ from the untreated control. Although the effects of reducing earthworms were variable and difficult to explain, our findings suggest that augmenting earthworm populations can suppress Verticillium wilt of eggplant, and strategies that increase earthworm numbers may contribute to disease suppression.
\end{abstract}

Verticillium wilt, caused by Verticillium dahliae Kleb., can be a major constraint on eggplant (Solanum melongena L.) production in the northeastern United States. Symptoms include wilt, chlorosis, defoliation, small leaves, and stunted plants. There are no highly resistant cultivars (16). Management options, such as fumigation and crop rotation, provide partial disease suppression, but they are not always desirable or practical. Previous research found that using black plastic mulch and ammonium sulfate fertilization provided more suppression of Verticillium wilt of eggplant than bare ground or application of calcium nitrate (14). Although the fertilization practices are available to conventional growers, they are not commonly used by organic growers. Organic growers typically use cover cropping and green manuring to reduce damage from Verticillium wilt. Regardless, any growers with Verticillium-infested fields who want to transition to organic practices can suffer major losses in the first few years until cover cropping and green manuring

Corresponding author: Wade H. Elmer

E-mail: Wade.Elmer@po.state.ct.us

Accepted for publication 11 January 2009

doi:10.1094/PDIS-93-5-0485

(C) 2009 The American Phytopathological Society reduce damage from soilborne diseases $(34,36,42)$.

Earthworm activity is an important component of soil health $(1,25)$. Charles Darwin (5) was one of the first to show their role in plant decomposition. Subsequent research showed that earthworm burrowing and processing of organic matter improves nutrient availability (35) and facilitates percolation of water into lower soil horizons $(13,19,44)$. Over the past decade, some studies have shown that earthworms were associated with disease suppression $(4,6,27,33)$. Vermicomposts, which are end-products of the breakdown of organic matter by earthworms, are disease-suppressive $(10,37,38)$. Diseases on asparagus, eggplants, and tomatoes that are caused by $V$. dahliae or certain Fusarium spp. were suppressed in greenhouse studies when soils were augmented with adult earthworms (15). Assays of rhizosphere soil revealed that the numbers $(\mathrm{CFU} / \mathrm{g})$ of fluorescent pseudomonads and filamentous actinomycetes were consistently greater in soils augmented with earthworms than in controls. These findings were consistent with several studies demonstrating that earthworm activity stimulates a greater and more diverse microbial population than that found in the surrounding soil $(29,32,40,41)$.

Conventional cultivation practices leave most soils with relatively low earthworm densities (20). Although earthworm levels usually increase when soils are left fallow, their recovery can be a function of the initial population level, availability of surface residues, soil $\mathrm{pH}$, climate, and the frequency and quantity of any chemical inputs $(9,11)$. Methods to increase earthworm densities in field soil include minimizing chemical inputs, liming acid soils to increase $\mathrm{pH}$ to 6.0 to 7.0 , and practicing minimum tillage to promote surface residues $(9,11,22)$. Earthworms can proliferate under good conditions and triple their numbers in a growing season (2). The Canadian nightcrawler, Lumbricus terrestris L., is well adapted for use in agriculture in the northern United States since it is a long-lived, cold-tolerant species that makes deep burrows beneath the frost line $(13,19)$. Researchers have attempted to augment fields with nightcrawlers to increase soil densities and achieve the benefits more rapidly $(2,12)$. Edwards and Lofty (12) found that introducing L. terrestris resulted in increased barley growth within a season and that the effects were still observed after the second season of barley. Supplementing soils with earthworms has been found useful in remediation of soils (2) and in efforts to distribute beneficial microbes throughout the soil horizons $(8,17,32)$. At present, it is not known whether augmenting earthworm populations in soil infested with fungal plant pathogens would suppress disease. The objectives of our report were to determine if augmenting Verticillium-infested soils with adult earthworms would affect the yield, plant growth, and development of Verticillium wilt of eggplant.

\section{MATERIALS AND METHODS}

Plot establishment. Eggplant cv. Black Beauty (Comstock Ferre Seed Co., Wethersfield, CT) seeds were germinated in the greenhouse in soilless potting mix in 36cell trays and fertilized twice with $100 \mathrm{ml}$ of 20-10-20 (N-P-K) Peter's soluble fertilizer (1.0 g/liter) (Scotts Inc., Lincoln, NE). One-month-old seedlings were used in all field experiments. Adults of L. terrestris were purchased from a fishing supply house (N.A.S. Inc., Marblehead, OH) each year. Earthworms were kept at $10^{\circ} \mathrm{C}$ for no more than 4 weeks. Earthworms were rinsed three times in tap water before being used.

Field trials were conducted during the 2005, 2006, and 2007 growing seasons at Lockwood Farm in Hamden, CT, on a Cheshire fine sandy loam (Typic Dystrocrept) (pH 6.1). The field had been planted 
to eggplants and other solanaceous hosts for over 20 years and had high populations of $V$. dahliae. Prior to the initiation of this study, 15 soil cores were removed to a depth of $15 \mathrm{~cm}$, bulked, and three samples were removed and assayed for $V$. dahliae by the method of Huisman and Ashworth (18), which estimated $13 \pm 5$ microsclerotia per $\mathrm{g}$ soil. The fields were covercropped each year with winter rye and plowed under on 1 June 2005, 2 June 2006, and 28 May 2007. Different parts of the field were used each year to avoid any residual effects from the treatment of the previous year(s).

In 2005 and 2006, square plots $(2.1 \times$ $2.1 \mathrm{~m}$ ) were trenched and lined with clear, rigid, 20 gauge, polyvinylchloride (PVC) plastic film $(1.27 \mathrm{~mm}$ thickness, $70 \mathrm{~cm}$ wide) (EPV Plastics Inc., Oxford, MA) to contain the earthworms. Trenches were dug approximately $36 \mathrm{~cm}$ deep so that the plastic vertically extended $30 \mathrm{~cm}$ out of the plot. Since horizontal movement of $L$. terrestris occurs mostly on the soil surface, the PVC plastic was sufficient to contain the earthworms in each plot. Plots were planted on 8 June 2005 and 10 June 2006 with four eggplant transplants that were evenly spaced $1.2 \mathrm{~m}$ apart, one in each quadrant, approximately $0.6 \mathrm{~m}$ from the plot edge. Three treatments were applied within 3 days of planting: (i) augmented earthworm treatment, (ii) reduced earthworm treatment, or (iii) untreated control. There were four replicate plots per treatment. Earthworm densities were augmented by supplementing plots with 75 adult earthworms (11 earthworms per $\mathrm{m}^{2}$ ). The soil surface was irrigated to break up soil surface crusts. Earthworms were individually placed on the soil surface approximately $15 \mathrm{~cm}$ apart in a uniform pattern where they immediately began burrowing. For the reduced earthworm treatments, plots were drenched with carbaryl (1.1 mg a.i./plot) applied as $50 \mathrm{ml}$ of Sevin SL (Bayer Crop Science, Research Triangle Park, NC) in 20 liters of water. Since $L$. terrestris feeds on plant residues on the soil surface, drenching the soil surface with the toxic carbaryl prevented earthworms from emerging from their burrows and feeding, and reduced their presence and activity in these plots. No attempt was made to determine how deep the chemical treatment penetrated the soil. This treatment was presumed effective in reducing earthworm activity since no castings and middens were observed in these plots during the season, whereas they were readily apparent in the other treatments. In 2005, all plots except the reduced treatments were covered the next day with 133 liters of composted leaf mold to suppress weeds and provide a food base for the earthworms. Weeds were removed weekly by hand. In 2006, all plots received composted leaf mold the day after treatments were applied. In both years, all plots re- ceived $22.6 \mathrm{~kg}$ of dehydrated cow manure (Agway Inc., North Haven, CT), applied 3 to 4 weeks after planting.

In 2007, the experimental treatments and design were altered. Plots were not separated by PVC film. Since the surface migration of $L$. terrestris is usually less than 1 to $2 \mathrm{~m}$, provided sufficient surface residues are present to discourage longdistance feeding forays (22), we spaced plots $1.2 \mathrm{~m}$ apart with untreated borders between the treated plots. Plots $(3.75 \times 1.2$ m) consisted of four plants spaced $0.75 \mathrm{~m}$ apart in rows spaced $1.2 \mathrm{~m}$ apart. There were five replicate plots per treatment arranged in a randomized block design. Plants were planted on 1 June 2007. Polypropylene landscape fabric (DeWitt Sunbelt, Sikeston, MO) was laid down between all plots allowing $5 \mathrm{~cm}$ between the plants and the landscape fabric. In addition, the reduced treatment was altered. Earthworms were removed from plots with a hot mustard soil extraction method (21). Although the removal of all earthworms is an unrealistic and unobtainable goal, this procedure was comparable to extracting earthworms by digging and sieving the soil (21). It is nonlethal to earthworms and is environmentally nontoxic. One hundred twenty grams of hot mustard powder (McCormick \& Company, Inc., Sparks, MD) was agitated in 1 liter of deionized water for $2 \mathrm{~h}$ to dissolve the active component, allyl isothiocyanate. The slurry was then added to 12 liters of tap water to yield a $10 \%$ suspension $(\mathrm{wt} / \mathrm{vol})$ that was poured onto the soil surface $(3.0 \mathrm{~m}$ long $\times 0.6 \mathrm{~m}$ wide) from a watering can. The landscape fabric was temporarily removed during the extraction. Approximately 15 min later, the treatment was repeated as suggested (21) to allow more of the suspension to penetrate the soil. As earthworms emerged from their burrows, they were removed, rinsed in water, counted, and distributed elsewhere. A mean of 15.6 (78 total) and 17.0 (82 total) earthworms were removed from each treated plot on 7 June and 20 July 2007, respectively. Seventy-five adult earthworms were applied to plots designated as augmented (11 earthworms per $\mathrm{m}^{2}$ ) as described before. Weeds that grew in between the landscape fabric were removed by hand.

Plant growth and disease measurements. Beginning 3 weeks after planting, plant canopies were measured for disease severity and canopy size every 1 or 2 weeks for 9 weeks in 2005, 9 weeks in 2006, and 6 weeks in 2007 as described previously (14). Disease severity (\%) was visually assessed by estimating the percentage of the attached foliage exhibiting symptoms of chlorosis and wilt. Since symptomatic leaves of eggplant rapidly defoliate and can leave holes in the canopy where sunlight passes through, we estimated canopy size and the fraction of ground cover observable from overhead to provide another estimate of plant health. Briefly, the elliptical shape of an eggplant canopy $\left(A, \mathrm{~m}^{2}\right)$ was estimated using the formula $A=[(L \times W) / 4] \times \pi$, where $L=$ length (m) and $W=$ width $(\mathrm{m})$ of the canopy measured from directly overhead with a meter rule. The fraction of groundcover was determined by visually estimating the fraction of the soil surface that could be seen within the elliptical shape of the canopy $(S)$. Canopy size $\left(\mathrm{m}^{2}\right)$ was then calculated in the equation: canopy size $=A \times(1$ $-S$ ). The area under the plant canopy growth curve (CGC, $\mathrm{m}^{2}$ days) (or area under the disease progress curve [AUDPC, disease days]) was computed (14). When symptoms first appeared on leaves of a plant, pieces of wilting petioles were surface-disinfested in $0.053 \%$ sodium hypochlorite for $1 \mathrm{~min}$, rinsed, and placed onto ethanol water agar supplemented with streptomycin sulfate (250 mg/liter) (26). Colonies of $V$. dahliae that grew from the petioles confirmed the presence of the pathogen, and no further isolations were made from plants in that plot. Marketable fruit were harvested, counted, and weighed every 4 to 5 days from late July through mid-September. At the final harvest, all remaining fruit were removed and weighed. The plant was cut at the soil line and weighed. There was no attempt to remove and measure root weights.

Statistical analyses. Each year, the experiments were arranged in randomized complete block designs. The experimental treatments were the same in 2005 and 2006, so the data from both years were analyzed for interactions between years and presented separately for each year if significant interactions were detected. Treatment effects were tested using SYSTAT V.10 (Cranes Software International Limited, Bangalore, Karnataka, INDIA) procedure for mixed model ANOVA with year and replication as random effects. The 2007 data were analyzed for treatment effects with replication as random effects. Means were separated using Tukey's test at $P<0.05$.

\section{RESULTS}

There were significant interactions between treatment and year for CGC, AUDPC, and the yield components, so data for each year are presented separately. The treatment $\times$ year interaction was a result of significantly more disease in untreated plots in 2006 than in 2005 ( $P<$ 0.01; Table 1). In 2005, plants grown in the augmented earthworm treatment had approximately twice the value for CGC, fruit numbers, fruit weight, and final plant weights than the untreated controls (Table 1). The AUDPC values were significantly less in the augmented treatment than in untreated controls $(P<0.001)$. The growth and yield variables were greater in the carbaryl drench compared to the untreated control $(P<0.001)$ and did not differ from 
the augmented treatment. However, plants in the reduced treatment had significantly larger AUDPC values than the untreated controls. The effect of the augmented earthworm treatment on disease severity in 2005 was an overall reduction in symptom expression during the season when compared to the untreated and reduced treatments (Fig. 1).

The augmented earthworm treatments resulted in similar trends in 2006 even though there was more disease in the untreated controls (Table 1). Compared to the untreated control, the augmented treatment increased the CGC, fruit number, fruit weight, and final plant weights and also reduced the AUDPC value. Eggplants in the reduced treatment had lower CGC values and final plant weights than the untreated control, but did not differ in yield or AUDPC values. The main effect of the augmented treatment on disease in 2006 was a delay in the onset of symptom expression when compared to the untreated plots (Fig. 1).

In 2007, when the experimental design was changed, eggplant plots augmented with earthworms still had larger CGC values and larger final plant weights than controls $(P<0.05)$, but there were no significant effects on yield (Table 1). The augmented treatment reduced the AUDPC values relative to the untreated controls. Plots that received the reduced treatment using the hot mustard extraction method did not differ in disease severity, growth, or yield from the untreated controls. As in 2006, the reduced treatment significantly delayed the onset of symptoms (Fig. 1).

\section{DISCUSSION}

The current study found that manually augmenting Verticillium-infested field plots with adult earthworms resulted in increased eggplant growth and yield in 2 out of 3 years, and reduced disease estimates of Verticillium wilt in all 3 years. Although the mechanism(s) governing disease suppression that could be attributed to earthworms was not addressed in this study, a previous greenhouse study found that earthworms increased population densities of fluorescent pseudomonads and filamentous actinomycetes (15). These microbes previously have been implicated in disease suppression $(23,27,37)$. Earthworm burrows are filled with microbially rich castings $(29,32,40,41)$. Presumably, rapidly growing roots would occupy these burrows and become exposed to high densities of beneficial organisms in earthworm castings. These microbes may suppress disease by one or more of many different mechanisms, such as competition, antagonism, and/or induced resistance $(23,38)$. Earthworm activity also increases the availability of nutrients that affect plant health, which in turn affects disease suppression $(7,24,31,35)$. Since one study found that the viability of microsclerotia of $V$. dahliae was not reduced after passage through the gut of the earthworm (28), it is unlikely that earthworms reduced inoculum. Given these reports, disease suppression is likely mediated through a microbial mechanism.

In both 2005 and 2006, yields were higher in augmented plots compared to untreated plots, but this was not observed in 2007. The earthworm-augmented treatment increased the CGC values and the final plant weights in 2007, but there was no corresponding increase in yield. One explanation could be that the earthworm activity in 2007 increased canopy size, but did not produce an increase in flowers or perhaps the flowers developed normally and then aborted. The authors have noticed that eggplants on occasion would abort their flowers without any observable cause, but still retain a healthy canopy (W. H. Elmer and F. J. Ferrandino, unpublished data). Tedeschi and Zerbi (39) found that high soil water potential was associated with eggplants that aborted their flowers. Although we did not measure soil water potential, this explanation cannot be supported by any large difference in the weather since cumulative rainfall for 2007 was $37.7 \mathrm{~cm}$, whereas it was 26.8 and 58.3 $\mathrm{cm}$ for 2005 and 2006, respectively. In addition, the minimum/maximum temperature means for each month of the growing season were similar among years.

Applying carbaryl to plots resulted in unexpected improvements in plant growth and yield. Since total earthworm numbers are difficult to monitor, it is not known if densities were reduced enough to have an effect, but the lack of middens and surface castings in this treatment suggested there was minimal activity. Roberts and Dorough (30) classified carbaryl as extremely toxic to earthworms $\left(\mathrm{LC}_{50}=1-10\right.$ $\mu \mathrm{g} / \mathrm{cm}^{2}$ ), and Cathey (3) considered it to be one of the most lethal insecticides available. We know of no reports that demonstrate that carbaryl can suppress Verticillium, and since the AUDPC values in the current study indicated significant disease was still present, we conclude that carbaryl did not suppress Verticillium wilt. In 2007, when earthworm populations were reduced by hot mustard extraction, we did not see any reduction in yield compared to the untreated control. Although more than 160 earthworms were manually extracted from these plots, it is still not clear if numbers were reduced enough to impact growth and disease. It is possible that another yieldlimiting pest was being suppressed by the carbaryl applications, but we have identified no candidates. We know of no reports that suggest carbaryl could affect soil fauna in a manner that could directly or

Table 1. Effect of augmenting or reducing earthworm (Lumbricus terrestris) densities on eggplant growth, yield, and area under the disease progress curve of Verticillium wilt in the field in 2005, 2006, and 2007

\begin{tabular}{|c|c|c|c|c|c|}
\hline $\begin{array}{l}\text { Year } \\
\text { Treatment } \\
\end{array}$ & $\begin{array}{c}\text { Canopy growth } \\
{\text { curve }\left(\mathbf{m}^{2} \text { days) }\right.}^{\mathrm{v}}\end{array}$ & $\begin{array}{l}\text { Number } \\
\text { of fruits }\end{array}$ & $\begin{array}{c}\text { Eggplant yield } \\
(\mathrm{kg} / \text { plant })^{\mathrm{w}}\end{array}$ & $\begin{array}{l}\text { Final plant } \\
{\text { weights }(g)^{x}}^{\text {. }}\end{array}$ & $\begin{array}{c}\text { AUDPC }^{y} \\
\text { (disease days) }\end{array}$ \\
\hline \multicolumn{6}{|l|}{2005} \\
\hline Untreated & $10.1 \mathrm{a}^{\mathrm{z}}$ & $5.7 \mathrm{a}$ & $2.08 \mathrm{a}$ & $533 \mathrm{a}$ & $398 \mathrm{~b}$ \\
\hline Reduced & $17.7 \mathrm{~b}$ & $11.2 \mathrm{~b}$ & $4.56 \mathrm{~b}$ & $945 \mathrm{~b}$ & $623 \mathrm{a}$ \\
\hline Augmented & $20.6 \mathrm{~b}$ & $12.0 \mathrm{~b}$ & $4.70 \mathrm{~b}$ & $1,071 \mathrm{~b}$ & $242 \mathrm{c}$ \\
\hline \multicolumn{6}{|l|}{2006} \\
\hline Untreated & $8.3 \mathrm{a}$ & $3.4 \mathrm{a}$ & $1.69 \mathrm{a}$ & $465 \mathrm{a}$ & $612 \mathrm{a}$ \\
\hline Reduced & $10.0 \mathrm{~b}$ & $4.5 \mathrm{ab}$ & $1.78 \mathrm{a}$ & $572 \mathrm{~b}$ & 689 a \\
\hline Augmented & $10.5 \mathrm{~b}$ & $5.0 \mathrm{~b}$ & $2.30 \mathrm{~b}$ & $581 \mathrm{~b}$ & $474 \mathrm{~b}$ \\
\hline \multicolumn{6}{|l|}{2007} \\
\hline Untreated & $3.5 \mathrm{a}$ & $8.2 \mathrm{a}$ & $2.02 \mathrm{a}$ & 966 a & $320 \mathrm{a}$ \\
\hline Reduced & $3.7 \mathrm{a}$ & $9.4 \mathrm{a}$ & $2.27 \mathrm{a}$ & $944 \mathrm{a}$ & $264 \mathrm{ab}$ \\
\hline Augmented & $4.8 \mathrm{~b}$ & $7.4 \mathrm{a}$ & $2.09 \mathrm{a}$ & $1,055 \mathrm{~b}$ & $221 \mathrm{~b}$ \\
\hline
\end{tabular}

u Plots were drenched with carbaryl in the reduced treatment in 2005 and 2006, and earthworms were manually extracted with a 10\% hot mustard suspensions in 2007. Adult earthworms (75 per plot) were added in the augmented treatment.

${ }^{v}$ Canopy growth curve ( $\mathrm{m}^{2}$ days); an integrated estimate of the plant canopy size $\left(\mathrm{dm}^{2}\right)$ measured weekly.

${ }^{\text {w }}$ Plots were $7 \mathrm{~m}^{2}$ and contained four plants.

${ }^{\mathrm{x}}$ Fresh weight of the aboveground growth.

${ }^{y}$ Area under the disease progress curve based on weekly estimates of disease severity.

${ }^{\mathrm{z}}$ Values represent the mean of four replicate plots (16 plants) for 2005 and 2006 and five replicate plots (20 plants) for 2007; values followed by differing letters are significantly different according to Tukey's test at $P=0.05$. 
indirectly affect Verticillium wilt of eggplant. Flea beetles (Epitrix fuscula Crotch) caused damage early in the season, but we have discounted any effect of carbaryl on these pests since it was applied as a soil drench and carbaryl is not systemic.

The current study poses the question: Is earthworm augmentation too expensive for growers to use? Since L. terrestris is very difficult to rear (2), most distributors obtain their earthworms from collectors who manually harvest the species from open lawns and golf courses (43). At the current cost of 5 to 7 cents per earthworm and an application rate of 5 to 10 earthworms per $\mathrm{m}^{2}$, augmenting a field would cost an un-

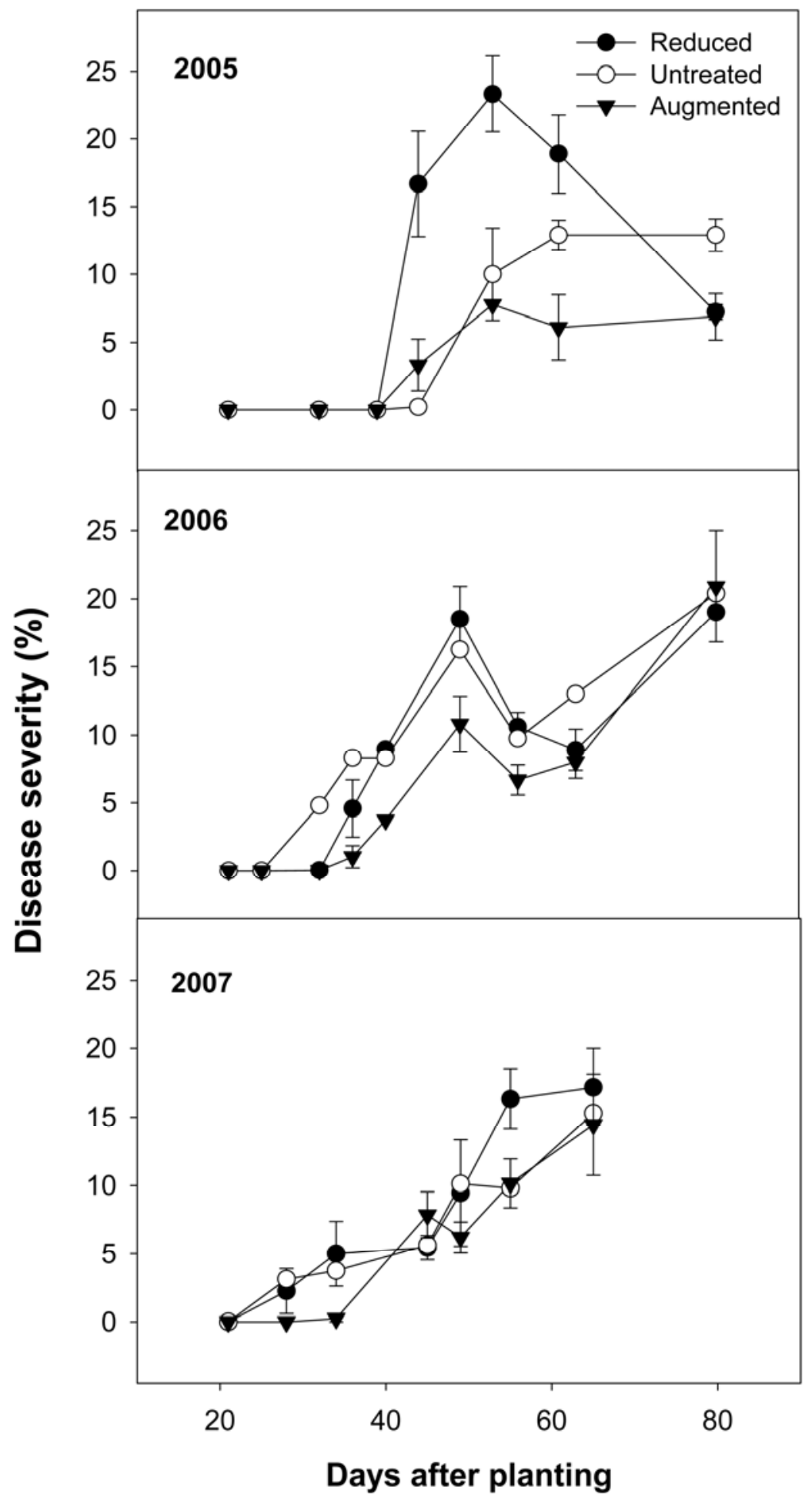

Fig. 1. Effect of earthworms (Lumbricus terrestris) on the development of Verticillium wilt symptoms (\% disease severity) of eggplants in plots infested with Verticillium dahliae. Treatments were: Augmented (adult earthworms added [11 $\left.\mathrm{m}^{2}\right]$ ), Reduced (treated with applications of carbaryl [2005 and 2006] or hot mustard suspensions [2007] to reduce earthworm densities), or Untreated. Error bars represent standard error of the mean $(P=0.05)$.

acceptable $\$ 2,500$ to $\$ 7,000$ per ha. Extracting and collecting earthworms from nearby pastures might serve as an alternative, but even this approach might be unacceptable on large acreage. Growers transitioning to organic farming should consider other management strategies that favor earthworms including liming, winter cover cropping, green manuring, minimum tillage, and minimizing chemical inputs. However, new technological advances in encapsulating earthworm cocoons for large-scale delivery into furrows of agronomic crops (Advanced Prairie Inc., Elliott, IL, U.S. Patent 5127186) may allow large and small growers to quickly increase earthworm densities provided the application is affordable. Our findings suggest that strategies to increase earthworm numbers and activity may, in turn, contribute to disease suppression.

\section{LITERATURE CITED}

1. Buckerfield, J. C., Lee, K. E., Davoren, C. W., and Hannay, J. N. 1997. Earthworms as indicators of sustainable production in dryland cropping in Southern Australia. Soil Biol. Biochem. 29:547-554.

2. Butt, K. R., Frederikson, J., and Morris, R. M. 1992. The intensive production of Lumbricus terrestris for soil remediation (Oloigachaeta Lumbricida). Pedobiologia 35:257-264.

3. Cathey, B. 1982. Comparative toxicities of five insecticides to the earthworm, Lumbricus terrestris. Agric. Environ. 7:73-81.

4. Clapperton, M. J., Lee, N. O., Binet, F., and Conner, R. L. 2001. Earthworms indirectly reduce the effect of take-all (Gaeumannomyces graminis var. tritici) on soft white spring wheat (Triticium aestivum cv. Fielder). Soil Biol. Biochem. 33:1531-1538.

5. Darwin, C. 1881. The Formation of Vegetable Mould Through the Action of Worms and Observation on their Habits. Murray Publishing Co., London.

6. Davoren, C. W., Ryder, M. H., and Doube, B. M. 1994. Ability of lumbricid earthworms Aporrectodea rosea and A. trapezoids to reduce the severity of take-all under greenhouse and field conditions. Soil Biol. Biochem. 26:1291-1297.

7. Devliegher, W., and Verstraete, W. 1997. The effect of Lumbricus terrestris on soil in relation to plant growth: Effects of nutrientenrichment processes (NEP) and gutassociated processes (GAP). Soil Biol. Biochem. 29:341-346.

8. Doube, B. M., Ryder, M. H., Davoren, C. W., and Meyer, T. 1995. Earthworms: A down under delivery system service for biocontrol agents of root disease. Acta Zoologica Fennica 196:219-223.

9. Edwards, C. A., ed. 1998. Earthworm Ecology. American Soil and Water Conservation Association/CRC Press/Lewis Publ., Boca Raton, FL.

10. Edwards, C. A., and Arancon, N. Q. 2004 Vermicomposts suppress plant pest and disease attacks. BioCycle 24:51-53.

11. Edwards, C. A., and Bohlen, P. J. 1996. The Biology and Ecology of Earthworms, 3rd ed. Chapman \& Hall, London.

12. Edwards, C. A., and Lofty, J. R. 1980. Effect of earthworms inoculation upon the roo growth of direct drilled cereals. J. Appl. Ecol. 17:533-543.

13. Ehlers, W. 1975. Observations on earthworm channels and infiltration on tilled and untilled loess soil. Soil Sci. 119:242-249. 
14. Elmer, W. H. 2000. Comparison of plastic mulch and nitrogen form on the incidence of Verticillium wilt of eggplant. Plant Dis. 84:1231-1234.

15. Elmer, W. H. 2009. Influence of earthworm activity on soil microbes and soilborne diseases of vegetables. Plant Dis. 93:175-179.

16. Ferrandino, F. J., and Elmer, W. H. 1993. Eggplant tolerance to Verticillium wilt. Biol. Cult. Control Tests 8:21.

17. Gange, A. C. 1993. Translocation of mycorrhizal fungi by earthworms during early succession. Soil Biol. Biochem. 25:1021-1026.

18. Huisman, O. C., and Ashworth, L. J., Jr. 1974. Verticillium albo-atrum: Quantitative isolation of microsclerotia from field soils. Phytopathology 64:1159-1163.

19. Joschko, M., Diestel, H., and Larink, O. 1982. Assessment of earthworm burrowing efficiency in compacted soil with a combination of morphological and soil physical measurements. Biol. Fert. Soils 8:191-196.

20. Kladivko, E. J., Akhouri, N. M., and Weesies, G. 1997. Earthworm populations and species distributions under no-till and conventional tillage in Indiana and Illinois. Soil Biol. Biochem. 29:613-615.

21. Lawrence, A. P., and Bowers, M. A. 2002. A test of the 'hot' mustard extraction method of sampling earthworms. Soil Biol. Biochem. 34:549-552.

22. Lee, K. E. 1985. Earthworms, their ecology and relationships with soils and land use. Academic Press, New York.

23. Lemanceau, P., and Alabouvette, C. 1993. Suppression of Fusarium wilts by fluorescent pseudomonads: Mechanisms and applications. Biocontrol Sci. Tech. 3:219-234.

24. Lunt, H. A., and Jacobson, H. G. M. 1944. The chemical composition of earthworm casts. Soil Sci. 58:367-375.
25. Muys, B., and Granval, P. 1997. Earthworms as bio-indicators of forest site quality. Soil Biol. Biochem. 29:323-328.

26. Nadakavukaren, M. J., and Horner, C. E. 1959. An alcohol agar medium selective for determining Verticillium microsclerotia in soil. Phytopathology 49:527-528.

27. Nakamura, Y. 1996. Interactions between earthworms and microorganisms in biological control of plant root pathogens. Farm. Jpn. 30:37-43.

28. Ndubizu, T. O. C. 1977. Effects of earthworms, nematodes, cultivations and host plants on Verticillium wilt of peach and cherry. Ann. Appl. Biol. 86:153-161.

29. Parle, J. N. 1963. A microbiological study of earthworm casts. J. Gen. Microbiol. 31:13-22.

30. Roberts, B. L., and Dorough, H. W. 1984. Relative toxicities of chemicals to the earthworm Eisenia foetida. Environ. Toxicol. Chem. 3:67-78.

31. Scheu, S. 2003. Effect of earthworms on plant growth: Patterns and perspectives. Pedobiologia 47:846-856

32. Schmidt, O., Doubre, B. M., Ryder, M. H., and Killman, K. 1997. Populations dynamics of Pseudomonas corrugata 2140R LUX8 in earthworm food and in earthworm cast. Soil Biol. Biochem. 29:523-528.

33. Stephens, P. M., and Davoren, C. W. 1997. Influence of the earthworms Aporrectodea trapezoides and $A$. rosea on the disease severity of Rhizoctonia solani on subterranean clover and ryegrass. Soil Biol. Biochem. 29:511-516.

34. Stone, A. G., Scheuerell, S. J., and Darby, J. M. 2004. Suppression of soilborne diseases in field agricultural systems: Organic matter management, cover cropping, and other cultural practices. Pages 131-177 in: Soil Organic Matter in Sustainable Agriculture. F. Magdoff and R. Weil, eds. CRC Press, Boca Raton, FL.
35. Subler, S., Baranski, C. M., and Edwards, C. A. 1997. Earthworm additions increased shortterm nitrogen availability and leaching in two grain-crop agroecosystems. Soil Biol. Biochem. 29:413-421.

36. Sumner, D. R., Doupnik, B., Jr., and Boosalis, M. G. 1981. Effects of reduced tillage and multiple cropping on plant diseases. Annu. Rev. Phytopathol. 19:167-187.

37. Szczech, M. 1999. Suppressiveness of vermicompost against Fusarium wilt of tomato. J. Phytopathol. 147:155-161.

38. Szczech, M., Kowalska, B., and Smolinska, U. 2002. Induction of systemic resistance in radish by pseudomonads developing in vermicompost-amended substrate. Phytopathol. Polonica 24:57-66.

39. Tedeschi, P., and Zerbi, G. 1985. Flowering and fruiting course and yield of eggplant ( $\mathrm{So}$ lanum melongena L.) plants grown in lysimometer with relations to different water regimes. Acta Hortic. 171:383-390.

40. Tiunov, A. V., and Scheu, S. 2000. Microfungal communities in soil litter and casts of Lumbricus terrestris (Lumbricidae): A laboratory experiment. Appl. Soil Ecol. 14:17-26.

41. Tiwari, S. C., and Mishra, R. R. 1992. Fungal abundance and diversity in earthworm casts and in uningested soil. Biol. Fert. Soils 16:131-134.

42. van Bruggen, A. C., and Termorshuizen, A. J. 2003. Integrated approaches to root disease management in organic farming systems. Australas. Plant Pathol. 32:141-156.

43. Wolfe, D. W. 2001. Tales from the underground: A natural history of subterranean life. Perseus Publishing, Cambridge, MA.

44. Zhang, H., and Schrader, S. 1993. Earthworm effects on selected physical and chemical properties of soil aggregates. Biol. Fert. Soils $15: 229-234$ 